SHS Web of Conferences 12,010 86 (2014)

DOI: $10.1051 /$ shsconf/ 20141201086

(C) Owned by the authors, published by EDP Sciences, 2014

\title{
Sustainable Highland Development through Stakeholders' Perceptions on Agro EcoTourism in Cameron Highlands: A Preliminary Finding
}

\author{
Ati Rosemary Mohd Ariffin ${ }^{1}$, Zuraini Md Ali ${ }^{2}$, Rosilawati Zainol ${ }^{3}$, Serina Rahman ${ }^{4}$, Ang Kean Hua ${ }^{5}$, \\ Norjumawati Sabran ${ }^{6}$ \\ ${ }^{1,5,6}$ Department of Architecture, Faculty of Built Environment, University of Malaya, Kuala Lumpur, \\ Malaysia \\ ${ }^{2}$ Department of Building Survey, Faculty of Built Environment, University of Malaya, Kuala Lumpur, \\ Malaysia \\ ${ }^{3}$ Department of Urban Planning, Faculty of Built Environment, University of Malaya, Kuala Lumpur, \\ Malaysia \\ ${ }^{4}$ UMCares - The Community \& Sustainability Centre, University of Malaya, Kuala Lumpur, Malaysia
}

\begin{abstract}
Cameron Highlands was discovered in 1885 and was developed as a hill station. It first served as a quaint retreat destination for the British residence where the urban morphology of its little town centres were strongly characterised by colonial architecture such as bungalows, institutional buildings and government offices, shophouses and market stalls. Eventually due to economic pressure and location potentials, more land was opened for tea plantations and vegetable and flower industries. Conversely, recent rapid uncontrolled developments in the built environment and agricultural sectors have tarnished its natural environment, old-world charm and historical values. If this trend persists, the popularity of Cameron Highlands as a vacation destination for local and foreign visitors may be badly affected. This research paper seeks to determine the perception of local stakeholders and tourists of the development in Cameron Highlands and whether they agree that agro-ecotourism can be used as a tool to achieve sustainability in the area. This paper is an assessment of a pilot test to determine initial perceptions toward Cameron Highlands development. The pilot test sample size was 41 respondents, comprising local authorities, local communities and NGOs, as well as local and international tourists. The results showed that the majority agreed that agroecotourism can generate a sustainable income and preserve the environment while ensuring sustainability through fair trade.
\end{abstract}

\section{Introduction}

Cameron Highlands was discovered by the British surveyor William Cameron in 1885 [1]. The area was later developed as a Hill Station by the British government. The Cameron Highlands countryside is endowed with invaluable historical and natural environments, and is a popular tourism destination in Malaysia. The highlands are also well known as one of the oldest and largest hill resorts in Malaysia [2]. During British colonial rule, Cameron Highlands was a popular rest area because of its cool climate and scenic settings. After the Malaysian independence in 1957, the highlands were promoted as a tourism destination and become more popular in the 1980 s with the availability of 
hotels and better roads. Thereafter, through the $9^{\text {th }}$ Malaysian Plan, the Malaysian government opened opportunities for farmers to expand and diversify agricultural products and other related industries, such as agrotourism. The importance of local participation in tourism was also promoted in the $7^{\text {th }}$ Malaysian Plan 1996 to 2000 [3]. All of these factors led to the development of agro-and ecotourism products. In general, agrotourism includes the promotion of areas such as tea plantations and strawberry farms, as well as vegetable and flower farms as tourism destinations; while ecotourism encompasses the promotion of forest reserves, forest trails/jungle trekking, waterfalls and rivers [4]. Initial tourism development in Cameron Highlands only focused on tea plantations [5].

\subsection{Marriage Between Agriculture and Ecotourism}

Agrotourism can be defined as 'any practice developed on a working farm with the purpose of attracting visitors' [6]. Meanwhile, ecotourism can be defined as 'responsible travel to natural areas that conserves the environment and improves the well-being of local people' [7]. Both tourism activities are believed to be able to bring economic value and increase visitor numbers to Cameron Highlands with less harm to the environment. For example, the natural ambiance and climate of a geographical location can increase tourist satisfaction levels [5]. In addition, agrotourism generates a steady income to farmers, eventually increases land value and also generates job opportunities to the community [5]. With increased tourist numbers local incomes and wages increase rapidly. These activities promote the economic value of Cameron Highlands and the country as a whole. A number of destinations worldwide use tea plantations as an agro-tourism attraction, such as Lembang in Indonesia [9] Nuwara Eliya in Sri Lanka [9], and Darjeeling in Indian Himalaya [10]. The natural environment is regularly used as ecotourism attractions, such as Taman Negara [11], Kota Kinabalu in Sabah [12], and Bario in Sarawak [13], all of which are in Malaysia.

\section{Cameron Highlands Issues \& Challenges}

Cameron Highlands has shown rapid development in agricultural and mass tourism since the 1980s. Past researches on Cameron Highlands has shown that there has been a reduction in its environmental quality as a result of recent rapid development. Monitoring highland areas and the scale of development has been difficult because of its high altitude and remoteness [14]. Illegal farming activities are also hard to curb. Sensible development and land use planning need to be take into consideration of the natural and sensitive habitats; serious damage could result from reckless overdevelopment [15]. A study by Yee and Chan (2006) concurs with this stand; they found that over development in highland areas is a main cause of landslides. St the same time, other studies have shown that Cameron Highlands' agricultural produce and tourism activities have contributed positively towards the country's economic growth.

Farming methods used is another issue to be considered in order to ensure sustainability. It has been highlighted that agriculture that permits the use of fertilizers, pesticides, and unsystematic agricultural practices, are factors that contribute to the degradation of environmental quality in highland areas [16]. Kunasekaran et al (2011) reports that agrotourism itself when not done is the correct manner can lead to air pollution; land development for tourism purposes will cause more pollution; mass development will increase temperature, negatively affecting agriculture, and agricultural pesticides and fertilizers will lead to environmental pollution. These multiple factors need to be taken into consideration as they too will affect the popularity of Cameron Highlands as a tourist destination. This has been shown by Hiong (2007) who reported that green scenery, peacefulness and unique biodiversity are among the expectations of visitors to Cameron Highlands. Hiong also expressed his concern about development activities, which would affect not only the area's natural beauty but also tourist satisfaction level. 


\section{Methodology}

The paper's main objective is to gather the perception of various stakeholders, pertaining to the environment, tourism activities, and acceptance and views of agro ecotourism. This paper is part of a larger research effort. In achieving its objectives, this study was carried out using a quantitative approach through questionnaire surveys. This survey is a pilot test carried out to examine the sustainability of highland communities, heritage and livelihoods through agro-ecotourism development in Cameron Highlands. The pilot test sample involved 41 respondents chosen randomly from the Tanah Rata area. The respondents include various Cameron Highlands stakeholders including five (5) people from the local authorities, and eighteen (18) people from the local community, including Orang Asli, business owners and Regional Environmental Awareness Cameron Highlands (REACH) representatives for non-governmental organizations (NGOs). In addition, eight (8) local tourists and ten (10) international tourists were also surveyed. The selected area for this pilot study was the Tanah Rata district, an area of rapid development after the Brinchang and Ringlet districts.

The questionnaire for the pilot test is divided into three (3) main sets, targeting the local authority, local community and NGOs, and tourists. The questionnaire has two sections; Section A focuses on demographic profiles while section B inquires about perceptions and impacts of agro-tourism. Some questions in section B differ between the three sets. For example, the questionnaires for the local authorities concentrates on environmental impacts, the questionnaire for local communities concentrates on business perspectives, and the questionnaire for tourists concentrates on their experience with agro-ecotourism. A large portion of the questions were prepared in Likert Scale, consisting of 5 parameters (1-strongly disagree, 2-disagree, 3-no comment, 4-agree, 5-strongly agree), with the total number of questions per set ranging from 20 to 25 questions. The study used the face-toface questionnaire survey method. The survey was audio recorded and photographs were taken as a record and for documentation purposes.

\section{Discussion}

The following sections will discuss the preliminary findings of the research:

\subsection{Local Authorities}

Five of the 41 respondents were staff from the local authorities. All respondents were Malaysian males in the civil service who had been in the civil service for more than five years and were also living permanently in Cameron Highlands. A majority of these respondents $(80 \%)$ were Malays and the remaining respondents were Indian. There are no Chinese participants in the government sector because most Chinese in Cameron Highlands are self-employed in private business. In this study, it was deemed important to determine education levels of the respondents so as to analyse the accuracy of their responses. However, this study showed that those who worked or lived in Cameron Highlands for a longer period of time were better able to answer the questions due to their longitudinal experience in the area rather than their education level. The analysis of the demographic profile was shown to have an impact on the perception of impacts of agro-tourism in Cameron Highlands. A majority of the respondents (90\%) were largely positive about the statement on the impact of agroecotourism. For example, most respondents agreed that the increase in land-use and development has negative impacts such as soil erosion and floods. It is thus important for local authorities to protect the environment by promoting environmental awareness to local communities and to take a bit of time to listen to public views. However, it was found that $80 \%$ of the respondents suggested that the local authority should provide incentive for agro-eco tourism in the study area. Furthermore, only $44 \%$ of the total respondents were satisfied with the agro tourism facilities provided by the local authority. Local authorities therefore need to promote agro-ecotourism, and provide more incentives and 
facilities to the local communities so that they can benefit from agro-ecotourism activities in Cameron Highlands.

\subsection{Local Communities \& NGOs}

Based on the analysis of the demographic profile of the local communities and NGO participants surveyed, the target of 18 questionnaires to be answered by this group of respondents was successfully achieved. Not dissimilar to the ethnicity mix that lives in Cameron Highlands, the majority of those who participated in this study were Malay, followed by Indians, and Orang Asli. The others participating in the survey included Sikh, and Chinese: both the Chinese respondents were Cantonese. In this group there were more male respondents than females. Most of the respondents work and live in Cameron Highlands, where most of them are private employees, in the farming and retail businesses. Even though a majority of the respondents do not have tertiary qualifications, the reliability of their answers can be accepted as they have lived and worked in Cameron Highlands for more than 10 years.

The pilot test showed that many understood that agrotourism is based on the agricultural sector. A majority of respondents $(61.1 \%)$ perceived that agriculture is the main attraction in Cameron Highlands, and an even higher percentage $(83.3 \%)$ perceived that tourism has positive impacts on the economic sustainability of Cameron Highlands. The local community also understood that tourism as it has been carried out thus far put pressure on the environmental sustainability and natural resources of Cameron Highlands, with a majority 'agreeing' to the statement given.

The results also showed that the locals agreed that uncontrolled tourism development had increased the temperature and changed the climate in Cameron Highlands. A majority of the respondents also agreed that switching to agro-ecotourism would increase the sustainability of economic, environmental and social aspects of their businesses. The local community also agreed that there should be strict regulation in land use. Although many believed that the local authorities did not necessarily consider public views, they did feel that the local authority and NGOs are committed to environmental issues.

\subsection{Local \& International Tourists}

The demographic survey results show that the 18 respondents that participated in the questionnaire were both local and international tourists. Apart from Malaysian tourists, the others were from Germany, Japan, Australia, and Canada. Most of the international tourists originated from temperature countries, thus proving that Cameron Highlands is still favoured for its pleasant and cool weather. A majority of respondents had tertiary education and professional jobs in their own country, and were willing to spend on their visit. About $64 \%$ of the respondents were satisfied with the Cameron Highlands environment, while the remaining respondents had 'no comment' or were 'dissatisfied' with the environment.

While a majority $(80 \%)$ agreed that preserving the natural environment and practising safer agricultural methods were necessary, they $(83 \%)$ believed that the existing tourism development trends had increased local temperatures and negatively affected the agricultural business. They were supportive of the idea of agro-ecotourism not only to increase the quality of life of local residents (61\%), but also as aids to educate and preserve the quality of the environment (67\%). Nevertheless, a few responded with 'no comment', perhaps indicating they were not clear about the meaning of agroecotourism.

The results also show that the tourists believed that mass tourism and uncontrolled visitor numbers had a negative impact on nature and the indigenous people. A majority $(67 \%)$ of the respondents felt that Cameron Highlands is suitable as a family tourist destination, and agreed that agro-ecotourism contributed to the survival of the Cameron Highlands community as agro-ecotourism enthusiasts would purchase local products and crafts. 


\section{Initial Results}

The analysis of the pilot test showed that the local authorities, local community and NGOs, as well as tourists generally agreed that agro-ecotourism can bring economic sustainability to Cameron Highlands and the country. However, rapid uncontrolled development and land use is perceived to have negative impacts on environmental sustainability, especially on the terrain and local climate as evidenced by increasing temperatures. The pilot test provided a brief insight into the need for Cameron Highlands to prosper with appropriate planning; in this case in agricultural and tourism decision-making. Thus, it is important for all stakeholders to frequently discuss pertinent issues and play a role in ensuring sustainability in highland development. For example, the local authorities should take more serious steps to preserve the environment, and be open to public views, as well as work on sustainable solutions especially in the agricultural sector. Local communities should come together to not only drive the economy of Cameron Highlands, but to take part in environmental community projects so as to meet social community needs and care for the environment. Tourist awareness of carrying capacity and limits of change, as well as sensitivity to the needs and privacy of the local community especially the indigenous people should be increased and emphasized.

\section{Conclusion}

The findings in this study show that the local authorities, local communities and NGOs support the idea that agro-ecotourism can boost the economic value of Cameron Highlands and the country. However, this is a huge challenge with illegal and uncontrolled land clearing which has resulted in various environmental problems and issues such as soil erosion and floods, and most importantly a change in the micro-climate. This will lead to a negative impact on the entire ecosystem and ecotourism businesses in Cameron Highlands, which are highly dependent on nature and cool climates. Past environmental awareness campaigns for the local community did little to change the situation. In conclusion, protecting the environment is not the sole responsibility of the local authorities, but local communities and NGOs should play a role in caring for the natural environment. Overall, this pilot study achieved its main target, even though there were several problems in the questionnaires that need to be fine-tuned and improved for the actual full-scale survey.

\section{Acknowledgement}

The authors would like to thank the University Malaya Research Grant Programme titled Historical Hill-Station Settlement as a Sustainable development area: the Case of Cameron Highland (UMRGRP009C-13SUS: Sustainable Highland Community, Heritage and Livelihood Through EcoAgo-tourism development in Cameron Highland) under the Sustainability Science Research Cluster which supported field and desk research that helped produce this paper.

\section{References}

1. Cameron Highlands District Council Official Portal (n.d). Background of Cameron Highlands District. Retrieved from http://www.mdcameron.gov.my/en/latar-belakang

2. Leong, Y.K. (1992). Conservation and Development of Cameron Highlands. Hill Development Proceedings of the Seminar, 20-31 (1992)

3. Government of Malaysia. Seventh Malaysia Plan, 1996-2000. Kuala Lumpur: Government Printers (1996)

4. N.H.M. Salleh, O. Redzuan, S.M.I. Hajar, A.M. Jaafar, \& P.S. Doris, The indigenous community's perception of tourism development in the Cameron Highlands, Malaysia: A preliminary study. Journal of Tourism, Hospitality \& Culinary Arts. 4, 77-87 (2012) 
5. K. Kunasekaran, S. Ramachandran, M.R Yacob \& A. Shuib, Development of farmers' perception scale on agro tourism in Cameron Highlands, Malaysia. Special Issue of Tourism \& Hospitality. 12, 10-18 (2011)

6. C. Barbieri \& P.M Mashenga. The role of the film and owner characteristics on the performance of agritourism farms. Sociologia Ruralis. 48, 166-183 (2008)

7. The International Ecotourism Society. What is Ecotourism? Retrieved from $\mathrm{http} / / / \mathrm{www}$.ecotourism.org/what is-ecotourism (1990)

8. Susan Coban. The Effects of the Image of Destination on Tourist Satisfaction and Loyalty: The Case of Cappadocia, European Journal of Social Sciences (2012)

9. Bandung Tourism (n.d). Retrieved from http://www.bandungtourism.com/search.php? $q=$ ciwidey

10. L.P Tirkey \& J.S Gardner. The ecological and socioeconomic implications of tea plantations of tea estate closure in Darjeeling, Indian Himalaya. International Symposium towards sustainable Livelihood and Ecosystem in Mountainous Regions. 7-9 March 2006, Chiang Mai, Thailand (2006)

11. Taman Negara Web Portal (n.d). Retrieved from http://www.taman-negara.com/

12. J. Mastura, K. Kayat, T.M. Tangit \& F. Yacob. Nature-based tourism and its economic benefits: a case study of Kinabalu National Park. Worldwide Hospitality and Tourism Themes. 5, 342 $352(2013)$

13. M. Jiwan, R. Alan \& P. Lepun. Agro-eco- tourism potential and benefits for sustaining Kelabit community in Bario. International Conference on Agricultural Extension: 1 - 10. (2008)

14. N.W. Chan. Cameron Highlands: Issues \& challenges in Sustainable Development. Penang: School of Humanities, Universiti Sains Malaysia, iv-v. (2006)

15. R.P. Lim \& S.W Lee. Hill development: Proceeding of the seminar. Malayan nature Society, Kuala Lumpur (1992)

16. S.K. Yee \& N.W Chan. Tourism in the Cameron Highlands: Issues, Prospects and Challenges. N Chan, N.W. (ed.) Cameron Highlands: Issues \& Challenges in Sustainable Development. Penang: School of Humanities, Universiti Sains Malaysia (2006)

17. Hiong, L.B. Pembangunan Ekopelancongan Di Cameron Highlands: Satu Kajian Kes. Universiti Sains Malaysia (2007)

18. Nuwara Eliya Web Portal (n.d). Retrieved from http://www.nuwaraeliya.org/ 